\title{
Human Health Risks Assessment of Some Heavy Metals in Oreochromis niloticus from a Tropical Reservoir
}

\author{
Adefemi Ajibare $^{1, *}\left(\mathbb{C}\right.$, , Peter Ogungbile ${ }^{2}\left(\mathbb{D}\right.$, Patrick Ayeku $^{3}\left(\mathbb{D}\right.$, John Akande $^{2}$
}

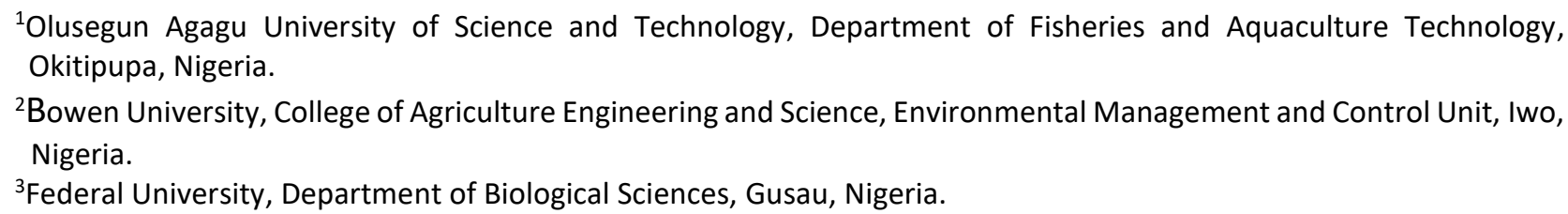

\section{How to cite}

Ajibare, A., Ogungbile, P., Ayeku, P., Akande, J. (2021). Human Health Risks Assessment of Some Heavy Metals in Oreochromis niloticus from a Tropical Reservoir. Aquatic Food Studies, 1(2), AFS35. https://doi.org/10.4194/AFS35

\section{Article History}

Received 09 August 2021

Accepted 19 October 2021

First Online 21 October 2021

Corresponding Author

Tel.: +2348034804486

E-mail: mrajifem@yahoo.com

\section{Keywords}

Food Safety

Dietary intake

Target hazard quotient

Carcinogenic risk

Environmental Pollution

\begin{abstract}
This study evaluated the human health risks of $\mathrm{Mn}, \mathrm{Fe}, \mathrm{Zn}, \mathrm{Cu}, \mathrm{Cd}, \mathrm{Pb}, \mathrm{Cr}$, $\mathrm{Co}$ and $\mathrm{Ni}$ in Oreochromis niloticus inhabiting Agodi reservoir in Ibadan, Nigeria. The metals' concentrations were determined with atomic absorption spectrophotometer. Carcinogenic and non-carcinogenic risk of consumers from the intake of metals in the fish was evaluated by Health Risk Index (HRI), Health quotient (HQ) Target Hazard Quotient (THQ) and Target cancer risk (TR). The metal concentrations in the fish were below the recommended limit by Environmental Protection Agencies. HRI and HQ of each examined metal was greater than one, indicating that there was potential noncarcinogenic health risk associated with the consumption of the fish. However, the THQ and TR were less than one. This indicated that Oreochromis niloticus will not pose any immediate carcinogenic threat to its consumers. It is therefore recommended that only eco-friendly activities should be permitted in/around aquatic ecosystems especially Agodi reservoir in order to keep contaminants below safety limit.
\end{abstract}

\section{Introduction}

Fish is a major part of Nigerian diet and is very susceptible to environmental pollution due to the activities and processes going on in and around the aquatic area. Fish is a source of energy and protein with high biological value, and contributes to the intake of essential nutrients, such as iodine, selenium, calcium, and vitamins $A$ and $D$, with well-established health benefits. It is recommended for the prevention of heart disease because it is low in total and saturated fats but provides $n-3$ (also called omega-3) long-chain polyunsaturated fatty acids. It is generally appreciated as one of the healthiest and cheapest source of protein because it has amino acid compositions that are higher in cysteine than most other source of protein (Orosun et al., 2016). Catfish and Tilapia are among the most popular fish consumed in Nigeria mainly due to their availability, taste and relatively low cost. Tilapia particularly, is the most common example of lower-fat fish that provide more of these heart-healthy nutrients (Carroll and Warwick, 2017). Hence, the need to evaluate the health risks of heavy metals in Oreochromis niloticus.

A general concern about the safety of foods and assessment of their risk to the general population has been on the increase in recent years (Jimoh et al., 2004, Dimari et al., 2008, Adeyeye and Ayoola 2010, Abubakar 
et al., 2014, Milam et al., 2012, Edward et al., 2013, Adesuyi et al., 2016; Manavia and Mazumder 2018; Akinola et al., 2019 \& 2020; Olawusi-Peters and Adejugbagbe, 2020). The concentrations of natural and synthetic chemical compounds in food contribute to its safety. Thus, heavy metals contamination is an important issue regarding the health of the aquatic animals which in turn affect the health of their consumers. Several studies have been done on the assessment of heavy metals on fish from different sources of water to evaluate the health risk that man and other consumers of fish may be exposed to (Adesuyi et al., 2016; Isibor and Imoobe, 2017; Olawusi-Peters et al., 2017; Olawusi-Peters et al., 2019; Omobepade et al., 2020; Olawusi-Peters and Adejugbagbe, 2020). According to Environmental Protection Agencies (EPAs), human health risk assessment is the estimation of the nature and probability of immediate or futuristic adverse health effects in humans exposed to chemicals in contaminated environmental media (Liu et al., 2019). Risk assessment for heavy metals is estimated using parameters such as estimated daily intake (EDI), target hazard quotient (THQ), hazard index ( $\mathrm{HI}$ ) and target cancer risk (TR) introduced by United States Environmental Protection Agency (USEPA 2011; Liu et al., 2019). These parameters depend not only on intake amount of contaminant but also deal with exposure frequency and duration, average body weight and oral reference dose (RfD) (Baki et al., 2018; Liu et al., 2018; Olawusi-Peters, 2021).

In Nigeria, the levels of heavy metals pollution in fish samples inhabiting some reservoirs such as Kainji Dam (Jimoh et al., 2004), Alau Dam (Dimari et al., 2008), Ikosi Dam (Adeyeye and Ayoola (2010), Kiri Dam (Milam et al., 2012), Ureje Dam (Edward et al., 2013), Awara Dam (Olawusi-Peters et al., 2019) have been investigated, and revealed that despite the valuable nutritional constituents of fish, their ability to bioaccumulate toxic and non-biodegradable heavy metals in their edible body parts needs adequate assessment of the concentration of heavy metals at regular intervals, so as to protect the consumers. Considering the potential toxicity, recalcitrant nature and cumulative behaviour of heavy metals as well as the frequency of fish consumption, its safety and health concerns, more research is needed to be done on all fish species consumed in Nigeria. Thus, this study monitored the concentrations of $\mathrm{Cd}, \mathrm{Pb}, \mathrm{Cr}, \mathrm{Mn}, \mathrm{Fe}, \mathrm{Co}, \mathrm{Ni}, \mathrm{Cu}$ and $\mathrm{Zn}$ in O. niloticus inhabiting Agodi reservoir and assessed the potential human health risk (carcinogenic and noncarcinogenic) associated with its consumption.

\section{Materials and Methods}

\section{Sample collection and preparation}

A total of two hundred and sixteen (216) samples (18 samples per month) of $O$. niloticus (average weight and length of $204.65 \pm 1.28 \mathrm{~g}$ and $15.50 \pm 0.84 \mathrm{~cm}$ respectively) were collected from Agodi reservoir, Ibadan Oyo State, Nigeria (3 56' 18" E and 70 26' 11" N) with the help of professional local fishermen between 2015 and 2016 and were identified according to Olaosebikan and Raji (2013). The fishes were captured with cast net. They were washed with distilled water and kept in ice box and then transferred to the research laboratory of the Department of Chemistry, Bowen University Iwo, Nigeria for analyses. The fish samples were dried in a laboratory oven at $60 \pm 1^{\circ} \mathrm{C}$ for $5-6$ hours.

\section{Estimation of heavy metals}

In the research laboratory of the Department of Chemistry, Bowen University Iwo, Nigeria; the fish samples were dissected to remove the muscles for the analysis. The muscles were oven dried at $60^{\circ} \mathrm{C}$ for 48hours and $1 \mathrm{~g}$ of the dried muscle tissue was digested in analytical grade $\mathrm{HNO}_{3}: \mathrm{HClO}_{4}(4: 1)$ according to Javed et al. (2015) and used for the estimation of heavy metals using Atomic Absorption Spectrophotometer (Model PG990). Analytical blanks were run in the same way as the samples and concentrations were determined using standard solutions prepared in the same acid matrix. The accuracy of the applied analytical procedure was tested using the certified reference material for investigated metals. Replicate analyses of these reference materials gave good accuracy, with recovery rates for metals between 96 and $104 \%$ for fish provided as supplementary material. Instrument calibration standards were made by diluting the standard (1000 ppm) supplied by Wako Pure Chemical Industry Ltd., Japan.

\section{Statistical Analyses}

Data obtained were subjected to descriptive statistics (to determine means and standard deviations) on the Statistical Package for Social Sciences (20.0) while the potential health risks of heavy metal consumption through $O$. niloticus were assessed based on health risk index (HRI) Health Quotient (HQ), the target hazard quotient (THQ), hazard index (HI) and target cancer risk (TR).

Health Risk Index (HRI) (which gives quantitative information on risk posed by each contaminant to the health of the fish consumers) was calculated as,

$$
\begin{aligned}
& \text { Health Risk Index } \\
& \qquad=\frac{\text { Daily Intake of Metal }(D I M)}{\text { Reference Oral Dose }(R f D)}
\end{aligned}
$$

(Olawusi-Peters and Adejugbagbe, 2020)

Where,

$$
\boldsymbol{D I} \boldsymbol{M}=\frac{M \times \text { Conversion Factor } \times W}{\text { Average body weight }}
$$

(Isibor and Imoobe, 2017) 
and $M$ is the concentration of metal in fish $(\mathrm{mg} / \mathrm{kg})$, Conversion Factor of 0.085 is to convert fresh fish weight to dry weight (Sajjad et al., 2009), $W$ is the dry weight of the fish consumed per/day and $48 \mathrm{~g} /$ day was estimated as the average fish consumption rate in Nigeria (Omobepade et al., 2020) while the average body weight used was $60 \mathrm{~kg}$ (Olawusi-Peters et al, 2019). Reference Oral Doses (RfD) was 0.040, 0.300, 0.700, $0.004,0.001,1.500,0.020,0.140$ and $0.020 \mathrm{mg} / \mathrm{kg} / \mathrm{day}$ for $\mathrm{Cu}, \mathrm{Zn}, \mathrm{Fe}, \mathrm{Pb}, \mathrm{Cd}, \mathrm{Cr}, \mathrm{Co}, \mathrm{Mn}$ and $\mathrm{Ni}$ respectively (USEPA, 2011; Olawusi-Peters and Adejugbagbe, 2020).

Health quotient (which estimates the hazard heavy metal could have on humans in their later life) was determined as:

$$
H Q=\frac{W \times M}{R f D \times B W}
$$

(Omobepade et al., 2020)

Where: $W$ is the dry weight of the fish consumed per/day,

$M$ is the concentration of heavy metal in the fish $(\mathrm{mg} / \mathrm{kg})$,

$R f D$ is the reference oral dose,

BW is the average body weight.

\section{Target Hazard Quotient (THQ)}

THQ (which is a dimensionless quantity that defines the exposure duration and the non-carcinogenic risk within the period) was calculated as,

$$
T H Q=\frac{E F r \times E D \times F I R \times M}{R f D \times B W \times A T n} \times 10^{-3}
$$

(Olawusi-Peters, 2021)

Where; EF is the exposure frequency (350 days/year); ED is the exposure duration (54 years, equivalent to the average life expectancy of the Nigerian population); FIR is the food ingestion rate (fish consumption values for south western adult Nigerian is $48 \mathrm{~g} /$ person/day) (Omobepade et al., 2020); $M$ is the metal concentration in the edible parts of fish $(\mathrm{mg} / \mathrm{kg})$; $\mathrm{RfD}$ is the oral reference dose; $\mathrm{BW}$ is the average body weight and ATn is the average exposure time for noncarcinogens (19710) (USEPA 2011).

\section{Hazard Index (HI)}

The hazard index ( $\mathrm{HI})$ which is expressed as the sum of the target hazard quotients was calculated as,

$$
H I=\sum_{n-1}^{n} T H Q \text { (Núñez et al., 2018) }
$$

Where; $n=$ number of heavy metals examined, $\mathrm{THQ}=$ unit $\mathrm{THQ}$ of ith heavy metal

\section{Target Cancer Risk (TR)}

Target cancer risk (TR) which indicates the carcinogenic risk (USEPA 2011) was calculated as,

$$
T R=\frac{M \times F I R \times C P S o \times E F \times E D}{B w \times A T n} \times 10^{-3}
$$

Where; M, FIR, EF, ED, BW are already explained above. ATn is the averaging time for carcinogens (365 days/ year $\times 54$ years, since in Nigeria the average life expectancy is approximately 54 years). CPSo is the carcinogenic potency slope oral ( $\mathrm{mg} / \mathrm{kg}$ bw-day-1). Since $\mathrm{Mn}, \mathrm{Fe}, \mathrm{Co}, \mathrm{Cu}$ and $\mathrm{Zn}$ do not cause any carcinogenic effects, their CPSo have not yet been established (USEPA 2012), TR values for intake of only $\mathrm{Ni}, \mathrm{Pb}, \mathrm{Cr}$ and $\mathrm{Cd}$ were calculated to show the carcinogenic risk, since they were mentioned in the list of potent carcinogens (USEPA 2012). Their carcinogenic potency slope oral (CPSo) as obtained from the integrated risk information system database (USEPA, 2012) is given as 1.7, 0.009, 0.5 and 0.6 for $\mathrm{Ni}, \mathrm{Pb}, \mathrm{Cr}$ and $\mathrm{Cd}$ respectively. According to New York State Department of Health (NYSDOH, 2007) and Javed and Usmani (2016) the TR categories are described as, if TR $\leq 10^{-6}=$ Low; $10^{-4}$ to $10^{-3}=$ moderate; $10^{-3}$ to $10^{-1}=$ high; $\geq 10^{-1}=$ very high

NOTE: Values below 1 for Target Hazard Quotient (THQ), Health Quotient (HQ), Health Risk Index (HRI) and Hazard Index (HI) are unlikely to result in any chronic systemic risk adverse health effects during a lifetime of exposure and would normally be considered as acceptable.

\section{Results}

The mean concentrations of metals obtained from the descriptive statistics recorded in this study were presented in Table 1 while the Daily intake of metals (DIM) was given in Table 2. HRI observed in this study (Table 3) was in the order of $\mathrm{Co}>\mathrm{Cd}>\mathrm{Mn}>\mathrm{Zn}>>\mathrm{Fe}>\mathrm{Cu}>\mathrm{Pb}>\mathrm{Ni}>\mathrm{Cr}$ and $\mathrm{Mn}>\mathrm{Co}>\mathrm{Zn}>\mathrm{Fe}>$ $\mathrm{Pb}>\mathrm{Cu}>\mathrm{Cd}>\mathrm{Ni}>\mathrm{Cr}$ in dry and wet season respectively. HRI was higher than one (i.e. $\mathrm{HRI}>1$ ) in all the examined heavy metals except $\mathrm{Cr}$ in both seasons. $\mathrm{HQ}$ (as presented in Table 4) was higher than one $(H Q>1)$ in all the examined heavy metals except $\mathrm{Cr}$ in dry seasons. The THQ values for $\mathrm{Cd}, \mathrm{Co}, \mathrm{Cr}, \mathrm{Cu}, \mathrm{Fe}, \mathrm{Mn}, \mathrm{Ni}, \mathrm{Pb}$ and $\mathrm{Zn}$ as presented in Table 5 were $1.83 \times 10^{-3}, 8.92 \times 10^{-3}, 0.00 \times 10$ $1,1.06 \times 10^{-4}, 2.92 \times 10^{-4}, 1.37 \times 10^{-3}, 4.07 \times 10^{-5}, 6.14 \times 10^{-5}$ and $4.77 \times 10^{-4}$ respectively in the dry season but were $7.67 \times 10^{-5}, 2.05 \times 10^{-3}, 1.11 \times 10^{-6}, 2.62 \times 10^{-4}, 4.70 \times 10^{-4}$, $2.62 \times 10^{-3}, 2.45 \times 10^{-5}, 4.18 \times 10^{-4}, 5.28 \times 10^{-4}$ and $6.44 \times 10^{-3}$ respectively in the wet season. THQ was less than 1 $(T H Q<1)$ in all the examined heavy metals throughout the study with the trend of $\mathrm{Co}>\mathrm{Cd}>\mathrm{Mn}>\mathrm{Zn}>\mathrm{Fe}>\mathrm{Cu}>\mathrm{Pb}>\mathrm{Ni}>\mathrm{Cr}$ and $\mathrm{Co}>\mathrm{Mn}>\mathrm{Zn}>\mathrm{Fe}>\mathrm{P}$ $\mathrm{b}>\mathrm{Cu}>\mathrm{Cd}>\mathrm{Ni}>\mathrm{Cr}$ in the dry and wet season respectively 
Table 1. Concentration of Metals $(\mathrm{mg} / \mathrm{kg})$ in O. niloticus inhabiting Agodi reservoir

\begin{tabular}{|c|c|c|c|c|c|c|c|c|c|}
\hline Month & $\mathrm{Cd}$ & Co & $\mathrm{Cr}$ & $\mathrm{Cu}$ & $\mathrm{Fe}$ & $\mathrm{Mn}$ & $\mathrm{Ni}$ & $\mathrm{Pb}$ & $\mathrm{Zn}$ \\
\hline Jan & $0.00 \pm 0.00$ & $0.00 \pm 0.00$ & $0.00 \pm 0.00$ & $1.36 \pm 0.45$ & $0.00 \pm 0.00$ & $63.33 \pm 15.42$ & $0.00 \pm 0.00$ & $0.00 \pm 0.00$ & $112.19 \pm 41.12$ \\
\hline Feb & $0.00 \pm 0.00$ & $0.00 \pm 0.00$ & $0.00 \pm 0.00$ & $5.19 \pm 3.93$ & $0.00 \pm 0.00$ & $16.00 \pm 27.71$ & $0.00 \pm 0.00$ & $0.00 \pm 0.00$ & $37.85 \pm 36.50$ \\
\hline Mar & $0.23 \pm 0.40$ & $0.00 \pm 0.00$ & $0.00 \pm 0.00$ & $4.22 \pm 3.20$ & $422.50 \pm 730.49$ & $21.83 \pm 18.13$ & $0.00 \pm 0.00$ & $1.79 \pm 3.10$ & $121.89 \pm 44.54$ \\
\hline April & $0.00 \pm 0.00$ & $0.00 \pm 0.00$ & $0.00 \pm 0.00$ & $3.73 \pm 0.92$ & $602.75 \pm 0.00$ & $43.17 \pm 8.86$ & $3.46 \pm 3.24$ & $0.00 \pm 0.00$ & $61.13 \pm 2.93$ \\
\hline May & $0.47 \pm 0.48$ & $1.30 \pm 2.25$ & $0.64 \pm 1.11$ & $27.42 \pm 33.94$ & $637.00 \pm 647.23$ & $1251.92 \pm 1100.14$ & $0.00 \pm 0.00$ & $13.50 \pm 21.38$ & $382.34 \pm 124.41$ \\
\hline June & $0.00 \pm 0.00$ & $2.06 \pm 1.10$ & $14.58 \pm 25.26$ & $33.93 \pm 23.40$ & $409.17 \pm 517.91$ & $986.50 \pm 1049.65$ & $0.00 \pm 0.00$ & $0.00 \pm 0.00$ & $91.53 \pm 74.44$ \\
\hline July & $0.00 \pm 0.00$ & $2.27 \pm 1.22$ & $0.00 \pm 0.00$ & $20.23 \pm 11.81$ & $896.83 \pm 673.03$ & $921.93 \pm 890.97$ & $0.00 \pm 0.00$ & $0.00 \pm 0.00$ & $365.82 \pm 324.23$ \\
\hline Aug & $0.00 \pm 0.00$ & $2.70 \pm 2.42$ & $0.00 \pm 0.00$ & $8.93 \pm 3.09$ & $1332.33 \pm 1107.07$ & $1003.08 \pm 756.67$ & $3.39 \pm 5.87$ & $1.61 \pm 0.00$ & $446.29 \pm 398.49$ \\
\hline Sept & $0.00 \pm 0.00$ & $0.00 \pm 0.00$ & $0.00 \pm 0.00$ & $3.75 \pm 5.76$ & $35.25 \pm 39.43$ & $41.00 \pm 26.38$ & $1.02 \pm 1.11$ & $0.00 \pm 0.00$ & $114.71 \pm 178.59$ \\
\hline Oct & $0.00 \pm 0.00$ & $0.00 \pm 0.00$ & $0.00 \pm 0.00$ & $2.19 \pm 0.59$ & $0.17 \pm 0.14$ & $78.08 \pm 65.85$ & $0.00 \pm 0.00$ & $0.00 \pm 0.00$ & $309.02 \pm 37.40$ \\
\hline Nov & $0.18 \pm 0.32$ & $14.75 \pm 25.55$ & $0.00 \pm 0.00$ & $3.59 \pm 3.28$ & $0.83 \pm 1.44$ & $124.92 \pm 22.12$ & $1.93 \pm 3.33$ & $0.00 \pm 0.00$ & $100.28 \pm 128.88$ \\
\hline Dec & $11.69 \pm 20.25$ & $0.00 \pm 0.00$ & $0.00 \pm 0.00$ & $8.61 \pm 7.80$ & $0.00 \pm 0.00$ & $46.42 \pm 36.78$ & $0.00 \pm 0.00$ & $0.00 \pm 0.00$ & $235.26 \pm 23.77$ \\
\hline Dry Season & $2.38 \pm 9.05$ & $3.49 \pm 11.37$ & $0.00 \pm 0.00$ & $5.54 \pm 4.78$ & $266.63 \pm 692.31$ & $250.75 \pm 484.94$ & $1.06 \pm 2.93$ & $0.32 \pm 1.25$ & $186.38 \pm 219.21$ \\
\hline Wet Season & $0.10 \pm 0.26$ & $0.80 \pm 1.33$ & $2.18 \pm 9.54$ & $13.64 \pm 18.64$ & $429.10 \pm 532.69$ & $477.78 \pm 762.58$ & $0.64 \pm 1.64$ & $2.18 \pm 8.34$ & $206.63 \pm 183.45$ \\
\hline WHO (2005) & 0.50 & 2.00 & 0.50 & 3.00 & 30.00 & 0.50 & 5.00 & 2.30 & 67.90 \\
\hline FAO (2007) & 0.20 & 2.00 & 0.50 & 3.00 & 30.00 & 0.50 & - & - & - \\
\hline
\end{tabular}


Table 2. Daily Intake of Metal (DIM) of O. niloticus inhabiting Agodi reservoir

\begin{tabular}{lccccccccc}
\hline Month & $\mathrm{Cd}$ & $\mathrm{Co}$ & $\mathrm{Cr}$ & $\mathrm{Cu}$ & $\mathrm{Fe}$ & $\mathrm{Mn}$ & $\mathrm{Ni}$ & $\mathrm{Pb}$ & $\mathrm{Zn}$ \\
\hline Jan & 0.00 & 0.00 & 0.00 & 0.09 & 0.00 & 4.31 & 0.00 & 0.00 & 7.63 \\
Feb & 0.00 & 0.00 & 0.00 & 0.35 & 0.00 & 1.09 & 0.00 & 0.00 & 2.57 \\
Mar & 0.02 & 0.00 & 0.00 & 0.29 & 28.73 & 1.48 & 0.00 & 0.12 & 8.29 \\
April & 0.00 & 0.00 & 0.00 & 0.25 & 40.99 & 2.94 & 0.24 & 0.00 & 4.16 \\
May & 0.03 & 0.09 & 0.04 & 1.86 & 43.32 & 85.13 & 0.00 & 0.92 & 26.00 \\
June & 0.00 & 0.14 & 0.99 & 2.31 & 27.82 & 67.08 & 0.00 & 0.00 & 6.22 \\
July & 0.00 & 0.15 & 0.00 & 1.38 & 60.98 & 62.69 & 0.00 & 0.00 & 24.88 \\
Aug & 0.00 & 0.18 & 0.00 & 0.61 & 90.60 & 68.21 & 0.23 & 0.11 & 30.35 \\
Sept & 0.00 & 0.00 & 0.00 & 0.26 & 2.40 & 2.79 & 0.07 & 0.00 & 7.80 \\
Oct & 0.00 & 0.00 & 0.00 & 0.15 & 0.01 & 5.31 & 0.00 & 0.00 & 21.01 \\
Nov & 0.01 & 1.00 & 0.00 & 0.24 & 0.06 & 8.49 & 0.13 & 0.00 & 6.82 \\
Dec & 0.80 & 0.00 & 0.00 & 0.59 & 0.00 & 3.16 & 0.00 & 0.00 & 16.00 \\
Dry Season & 0.16 & 0.24 & 0.00 & 0.38 & 18.13 & 17.05 & 0.07 & 0.02 & 12.67 \\
Wet Season & 0.01 & 0.05 & 0.15 & 0.93 & 29.18 & 32.49 & 0.04 & 0.15 & 14.05 \\
\hline
\end{tabular}

Table 3. Health Risk Index (HRI) of O. niloticus inhabiting Agodi reservoir

\begin{tabular}{|c|c|c|c|c|c|c|c|c|c|}
\hline Month & $\mathrm{Cd}$ & Co & $\mathrm{Cr}$ & $\mathrm{Cu}$ & $\mathrm{Fe}$ & $\mathrm{Mn}$ & $\mathrm{Ni}$ & $\mathrm{Pb}$ & $\mathrm{Zn}$ \\
\hline Jan & 0.00 & 0.00 & 0.00 & 2.31 & 0.00 & 30.76 & 0.00 & 0.00 & 25.43 \\
\hline Feb & 0.00 & 0.00 & 0.00 & 8.83 & 0.00 & 7.77 & 0.00 & 0.00 & 8.58 \\
\hline Mar & 15.87 & 0.00 & 0.00 & 7.17 & 41.04 & 10.60 & 0.00 & 30.46 & 27.63 \\
\hline April & 0.00 & 0.00 & 0.00 & 6.35 & 58.55 & 20.97 & 11.76 & 0.00 & 13.86 \\
\hline May & 31.73 & 294.67 & 0.03 & 46.61 & 61.88 & 608.07 & 0.00 & 229.50 & 86.66 \\
\hline June & 0.00 & 466.56 & 0.66 & 57.69 & 39.75 & 479.16 & 0.00 & 0.00 & 20.75 \\
\hline July & 0.00 & 513.78 & 0.00 & 34.40 & 87.12 & 447.80 & 0.00 & 0.00 & 82.92 \\
\hline Aug & 0.00 & 612.00 & 0.00 & 15.17 & 129.43 & 487.21 & 11.53 & 27.34 & 101.16 \\
\hline Sept & 0.00 & 0.00 & 0.00 & 6.38 & 3.42 & 19.91 & 3.46 & 0.00 & 26.00 \\
\hline Oct & 0.00 & 0.00 & 0.00 & 3.73 & 0.02 & 37.93 & 0.00 & 0.00 & 70.04 \\
\hline Nov & 12.47 & 3343.33 & 0.00 & 6.11 & 0.08 & 60.67 & 6.55 & 0.00 & 22.73 \\
\hline Dec & 795.03 & 0.00 & 0.00 & 14.63 & 0.00 & 22.55 & 0.00 & 0.00 & 53.33 \\
\hline Dry Season & 161.84 & 791.07 & 0.00 & 9.42 & 25.90 & 121.79 & 3.60 & 5.44 & 42.25 \\
\hline Wet Season & 6.80 & 181.33 & 0.10 & 23.19 & 41.68 & 232.06 & 2.18 & 37.06 & 46.84 \\
\hline
\end{tabular}

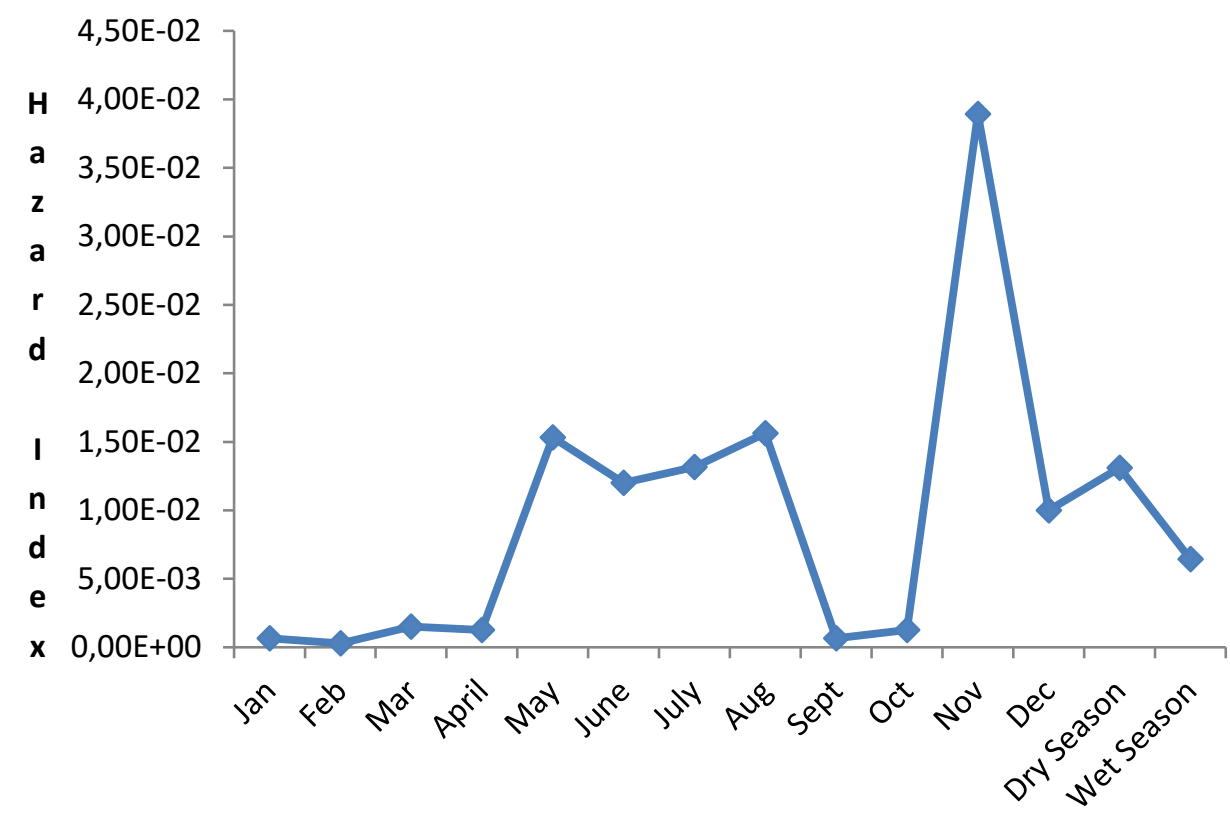

Figure 1. Hazard Index (HI) of $O$. Niloticus Inhabiting Agodi Reservoir 
and would be considered as acceptable. Also, Figure 1 revealed that the $\mathrm{HI}$ for the dry $\left(1.31 \times 10^{-2}\right)$ and wet $\left(6.44 \times 10^{-3}\right)$ seasons were less than one (i.e. $\mathrm{HI}<1$ ) and are unlikely to result in any chronic systemic risk adverse health effects during a lifetime of exposure.

The TR values for $\mathrm{Ni}, \mathrm{Cd}, \mathrm{Cr}$ and $\mathrm{Pb}$ (as presented in Table 5) were $1.38 \times 10^{-3}$ (Moderate risk), $1.10 \times 10^{-3}$ (Moderate risk), $0.00 \times 10^{1}$ (Low/No risk) and $2.21 \times 10^{-6}$ (Low risk) respectively in the dry season with corresponding values of $8.35 \times 10^{-4}$ (Moderate risk), $4.60 \times 10^{-5}$ (Low risk), $8.36 \times 10^{-4}$ (Moderate risk) and $1.51 \times 10^{-5}$ (Low risk) in the wet season. The result showed that higher TR values were recorded in the dry season for $\mathrm{Ni}$ and $\mathrm{Cd}$ while the order was reversed for $\mathrm{Cr}$ and $\mathrm{Pb}$. Also, the trend was $\mathrm{Ni}>\mathrm{Cd}>\mathrm{Pb}>\mathrm{Cr}$ and $\mathrm{Cr}>\mathrm{Ni}>\mathrm{Cd}>\mathrm{Pb}$ in the dry and wet season respectively.

\section{Discussion}

Results from this study indicated that the concentrations of heavy metals were lower than the values recommended for human consumption by World Health Organisation (WHO, 2005) and Food and Agriculture Organisation (FAO, 2007). Comparatively, the concentrations recorded for all the metals were lower than the value recorded by Ramos, (2012), Rajeshkumar and Li, (2018) and Manavia and Mazumder, (2018). Although, these differences can be attributed to variations in the study area, the size, age, sex and the physiological status of the fish (Manavia and Mazumder, 2018). Other factors such as fishing seasons, microbial activity and heavy metals content in sediment, water chemistry characteristics (dissolved organic content, salinity, $\mathrm{pH}$, and redox potential) assay methods should be considered.

The health risk index shows an individual's risks of heavy metal exposure based on body weight. Generally, $\mathrm{HRI}<1$ means that the exposed population is safe of metals health risk while HRI $>1$ means the opposite (Orosun et al., 2016, Olawusi-Peters, 2021). The health risk assessment of these heavy metals revealed that all the heavy metals will pose various non-carcinogenic health risks to the consumers since the HRI values of all the metals were higher than 1 . This observation is similar to the observation of Onuoha et al., (2016) and Isibor and Imoobe, (2017) but is at variance with the findings of Abubakar et al., (2014) and Olawusi-Peters and Adejugbagbe, (2020) who observed HRI values of less than 1 for imported frozen fish (Trachurus Murphyi) sold in Zaria metropolis and for Clarias gariepinus from Akure metropolis, in Nigeria.

Onuoha et al., (2016) and Olawusi-Peters (2021) reported that even though the HQ-based assessment method does not provide a quantitative estimate for the probability of an exposed population experiencing a reverse health effect, it indeed indicates the risk level due to exposure to pollutants. The Health quotient estimated for all metals had values higher than 1 . This observation is in line with the findings of Abubakar et al., (2014) who observed HQ values higher than 1 for Trachurus murphyi sold in Zaria metropolis, Nigeria but is at variance with the findings of Olawusi-Peters and Adejugbagbe, (2020) and Omobepade et al., (2020) who obtained values of less than 1 for Clarias gariepinus and Nematopalaemon hastatus from Akure metropolis and the coastal waters of Ondo State respectively. This implies that the consumers of $O$. niloticus are at risk of the heavy metals ( $\mathrm{Cd}, \mathrm{Cr}, \mathrm{Co}, \mathrm{Cu}, \mathrm{Fe}, \mathrm{Pb}, \mathrm{Ni}, \mathrm{Mn}$, and $\mathrm{Zn}$ ) in their later life. Li et al. (2014) and Omobepade et al., (2020) stated that a high value of hazard quotient poses relatively high potential health risks to human beings especially for those residing in areas with serious metal pollution. Therefore, the relatively low $\mathrm{HQ}$ value recorded in this study means the potential risk is low. $\mathrm{HRI}$ and $\mathrm{HQ}$ implied that there was immediate and future non-carcinogenic health risk for the consumers of the fish.

THQ parameter does not estimate the risk; it only indicates a level of risk associated with exposure to pollutants; if the value of $\mathrm{THQ}<1$, it means that there are no adverse effects for the exposed population; when THQ $>1$, there is a potential risk related to the metal studied in the exposed population (Al-Mahaqeri and Ahmad, 2015). THQ values of heavy metals ( $\mathrm{Cd}, \mathrm{Cr}$, Co, $\mathrm{Cu}, \mathrm{Fe}, \mathrm{Pb}, \mathrm{Ni}, \mathrm{Mn}$, and $\mathrm{Zn}$ ) were below one (THQ $>1)$ and this means that the metals would not pose any serious health hazards on the consuming population. This observation was similar to the report of Vieira et al. (2011) in Portugal while Falcoä et al. (2006) and Chahid (2016) recorded higher values for adults in Spain and Morocco respectively. Olawusi-Peters et al., (2019) and Olawusi-Peters and Adejugbagbe, (2020) also reported higher THQ ( $\mathrm{Cd}, \mathrm{Pb}$, and $\mathrm{Ni}$ ) for fish species in Awara reservoir and Akure metropolis of Ondo State Nigeria respectively. Hence, the consumption of $O$. niloticus does not pose health risk concern.

THQ deal with individual heavy metal, but generally food items contain more than one heavy metal. Since $\mathrm{HI}$ gives the sum of the target hazard quotients (THQs) for substances that affect the same organ or target organ systems (USEPA, 2017), hazard index $(\mathrm{HI})$ was therefore calculated for the nine heavy metals and revealed that the inhabitants were not exposed to health risks associated to these metals because the $\mathrm{HI}$ in all the metals was far less than 1 . THQ and $\mathrm{HI}$ revealed that there was no non-carcinogenic risk for the consumption of the fish (Baki et al., 2018; Liu et al., 2018).

Like THQ the estimated lifetime cancer risk (TR) is also not a specific estimate of expected cancers. Rather, it is apparently an upper limit of the probability that the individuals may have cancer sometime in their lifetime following exposure to that toxicant (NYSDOH 2007; Javed and Usmani, 2016). According to USEPA methods, cancer risk lower than $10^{-6}$ is considered to be negligible, $>10^{-4}$ is considered unacceptable, and in the range from $10^{-4}$ to $10^{-6}$ is considered acceptable (USEPA, 
Table 3. Health Quotient (HQ) of O. niloticus inhabiting Agodi reservoir

\begin{tabular}{lccccccccc}
\hline Month & $\mathrm{Cd}$ & $\mathrm{Co}$ & $\mathrm{Cr}$ & $\mathrm{Cu}$ & $\mathrm{Fe}$ & $\mathrm{Mn}$ & $\mathrm{Ni}$ & $\mathrm{Pb}$ \\
\hline Jan & 0.00 & 0.00 & 0.00 & 27.17 & 0.00 & 361.90 & 0.00 & 0.00 & 299.18 \\
Feb & 0.00 & 0.00 & 0.00 & 103.83 & 0.00 & 91.43 & 0.00 & 0.00 & 100.93 \\
Mar & 186.67 & 0.00 & 0.00 & 84.33 & 482.86 & 124.76 & 0.00 & 358.33 & 325.04 \\
April & 0.00 & 0.00 & 0.00 & 74.67 & 688.86 & 246.67 & 138.33 & 0.00 & 163.00 \\
May & 373.33 & 3466.67 & 0.34 & 548.33 & 728.00 & 7153.81 & 0.00 & 2700.00 & 1019.58 \\
June & 0.00 & 5488.89 & 7.78 & 678.67 & 467.62 & 5637.14 & 0.00 & 0.00 & 244.07 \\
July & 0.00 & 6044.44 & 0.00 & 404.67 & 1024.95 & 5268.19 & 0.00 & 0.00 & 975.51 \\
Aug & 0.00 & 7200.00 & 0.00 & 178.50 & 1522.67 & 5731.90 & 135.67 & 321.67 & 1190.11 \\
Sept & 0.00 & 0.00 & 0.00 & 75.00 & 40.29 & 234.29 & 40.67 & 0.00 & 305.89 \\
Oct & 0.00 & 0.00 & 0.00 & 43.83 & 0.19 & 446.19 & 0.00 & 0.00 & 824.04 \\
Nov & 146.67 & 39333.33 & 0.00 & 71.83 & 0.95 & 713.81 & 77.00 & 0.00 & 267.42 \\
Dec & 9353.33 & 0.00 & 0.00 & 172.17 & 0.00 & 265.24 & 0.00 & 0.00 & 627.36 \\
Dry Season & 1904.00 & 9306.67 & 0.00 & 110.80 & 304.72 & 1432.86 & 42.40 & 64.00 & 497.01 \\
Wet Season & 80.00 & 2133.33 & 1.16 & 272.80 & 490.40 & 2730.17 & 25.60 & 436.00 \\
\hline
\end{tabular}

Table 4. Target Hazard Quotient (THQ) of $O$. Niloticus Inhabiting Agodi Reservoir

\begin{tabular}{|c|c|c|c|c|c|c|c|c|c|}
\hline month & $\mathrm{Cd}$ & Co & $\mathrm{Cr}$ & $\mathrm{Cu}$ & $\mathrm{Fe}$ & $\mathrm{Mn}$ & $\mathrm{Ni}$ & $\mathrm{Pb}$ & $\mathrm{Zn}$ \\
\hline Jan & $0.00 \times 10^{1}$ & $0.00 \times 10^{1}$ & $0.00 \times 10^{1}$ & $2.61 \times 10^{-5}$ & $0.00 \times 10^{1}$ & $3.47 \times 10^{-4}$ & $0.00 \times 10^{1}$ & $0.00 \times 10^{1}$ & $2.87 \times 10^{-4}$ \\
\hline Feb & $0.00 \times 10^{1}$ & $0.00 \times 10^{1}$ & $0.00 \times 10^{1}$ & $9.96 \times 10^{-5}$ & $0.00 \times 10^{1}$ & $8.77 \times 10^{-5}$ & $0.00 \times 10^{1}$ & $0.00 \times 10^{1}$ & $9.68 \mathrm{E}-05$ \\
\hline Mar & $1.79 \times 10^{-4}$ & $0.00 \times 10^{1}$ & $0.00 \times 10^{1}$ & $8.09 \times 10^{-5}$ & $4.63 \times 10^{-4}$ & $1.20 \times 10^{-4}$ & $0.00 \times 10^{1}$ & $3.44 \times 10^{-4}$ & $3.12 \times 10^{-4}$ \\
\hline April & $0.00 \times 10^{1}$ & $0.00 \times 10^{1}$ & $0.00 \times 10^{1}$ & $7.16 \times 10^{-5}$ & $6.61 \times 10^{-4}$ & $2.37 \times 10^{-4}$ & $1.33 \times 10^{-4}$ & $0.00 \times 10^{1}$ & $1.56 \times 10^{-4}$ \\
\hline May & $3.58 \times 10^{-4}$ & $3.32 \times 10^{-3}$ & $3.28 \times 10^{-7}$ & $5.26 \times 10^{-4}$ & $6.98 \times 10^{-4}$ & $6.86 \times 10^{-3}$ & $0.00 \times 10^{1}$ & $2.59 \times 10^{-3}$ & $9.78 \times 10^{-4}$ \\
\hline June & $0.00 \times 10^{1}$ & $5.26 \times 10^{-3}$ & $7.46 \times 10^{-6}$ & $6.51 \times 10^{-4}$ & $4.48 \times 10^{-4}$ & $5.41 \times 10^{-3}$ & $0.00 \times 10^{1}$ & $0.00 \times 10^{1}$ & $2.34 \times 10^{-4}$ \\
\hline July & $0.00 \times 10^{1}$ & $5.80 \times 10^{-3}$ & $0.00 \times 10^{1}$ & $3.88 \times 10^{-4}$ & $9.83 \times 10^{-4}$ & $5.05 \times 10^{-3}$ & $0.00 \times 10^{1}$ & $0.00 \times 10^{1}$ & $9.35 \times 10^{-4}$ \\
\hline Aug & $0.00 \times 10^{1}$ & $6.90 \times 10^{-3}$ & $0.00 \times 10^{1}$ & $1.71 \times 10^{-4}$ & $1.46 \times 10^{-3}$ & $5.50 \times 10^{-3}$ & $1.30 \times 10^{-4}$ & $3.08 \times 10^{-4}$ & $1.14 \times 10^{-3}$ \\
\hline Sept & $0.00 \times 10^{1}$ & $0.00 \times 10^{1}$ & $0.00 \times 10^{1}$ & $7.19 \times 10^{-5}$ & $3.86 \times 10^{-5}$ & $2.25 \times 10^{-4}$ & $3.90 \times 10^{-5}$ & $0.00 \times 10^{1}$ & $2.93 \times 10^{-4}$ \\
\hline Oct & $0.00 \times 10^{1}$ & $0.00 \times 10^{1}$ & $0.00 \times 10^{1}$ & $4.20 \times 10^{-5}$ & $1.83 \times 10^{-7}$ & $4.28 \times 10^{-4}$ & $0.00 \times 10^{1}$ & $0.00 \times 10^{1}$ & $7.90 \times 10^{-4}$ \\
\hline Nov & $1.41 \times 10^{-4}$ & $3.77 \times 10^{-2}$ & $0.00 \times 10^{1}$ & $6.89 \times 10^{-5}$ & $9.13 \times 10^{-7}$ & $6.84 \times 10^{-4}$ & $7.38 \times 10^{-5}$ & $0.00 \times 10^{1}$ & $2.56 \times 10^{-4}$ \\
\hline Dec & $8.97 \times 10^{-3}$ & $0.00 \times 10^{1}$ & $0.00 \times 10^{1}$ & $1.65 \times 10^{-4}$ & $0.00 \times 10^{1}$ & $2.54 \times 10^{-4}$ & $0.00 \times 10^{1}$ & $0.00 \times 10^{1}$ & $6.02 \times 10^{-4}$ \\
\hline Dry Season & $1.83 \times 10^{-3}$ & $8.92 \times 10^{-3}$ & $0.00 \times 10^{1}$ & $1.06 \times 10^{-4}$ & $2.92 \times 10^{-4}$ & $1.37 \times 10^{-3}$ & $4.07 \times 10^{-5}$ & $6.14 \times 10^{-5}$ & $4.77 \times 10^{-4}$ \\
\hline Wet Season & $7.67 \times 10^{-5}$ & $2.05 \times 10^{-3}$ & $1.11 \times 10^{-6}$ & $2.62 \times 10^{-4}$ & $4.70 \times 10^{-4}$ & $2.62 \times 10^{-3}$ & $2.45 \times 10^{-5}$ & $4.18 \times 10^{-4}$ & $5.28 \times 10^{-4}$ \\
\hline
\end{tabular}


2011). Thus the results of this study revealed that the carcinogenic risk for the examined metals falls within the acceptable or lower than the negligible level. This was similar to the observations of Raknuzzaman et al., (2016) and Liu et al., (2018). TR indicated that there was no carcinogenic risk associated with the consumption of the fish. However, if anthropogenic interference on the ecosystem is not controlled/monitored, there is high tendency that the risk will increase with time. Thus, activities that may increase the tendencies of contaminants in the study area should be regulated so as not to increase the concentrations of heavy metals viz. a viz. the health risks.

\section{Conclusion}

This study provided information on heavy metals concentration in $O$. niloticus and its associated health risk for existing and prospective consumers in and around Agodi reservoir in Oyo State, Nigeria. All the metals detected were below the values recommended by FAO and WHO. HRI quantifies risks posed by each metal on the health of the fish consumers, hence the values higher than the threshold (1) indicated that there may be overall non-carcinogenic health risks due to consumption of the fish. This is buttressed by the result of $\mathrm{HQ}$ which estimates the effects of heavy metals on humans in their later life. However, THQ which defines the hazard in relation to exposure duration shows that the fish currently have no negative effect on the consumers since THQ for each metal was less than 1 . Also, $\mathrm{HI}$ which expresses the effects of all examined minerals on the consumers revealed that there is currently no health issue caused by the consumption of the fish. Also, TR suggested that the exposure doses of most elements for human consumption were safe for carcinogenic risk. Therefore, the entire human population who consumes $O$. niloticus from Agodi reservoir can continually depend on its supply. However, if all other routes of entry of heavy metal are considered the potential health risks for consumers might be increased. It is therefore, recommended that considerable attention should be given to the potential health risk of heavy metals via other exposure pathways such as other dietary sources (grains, livestock, vegetables/fruits, and water), inhalation, and skin exposure, since fish only accounted for a part of the human diet. Summarily, fishes dwelling in contaminated waters should be consumed with caution lest it may cause carcinogenic and non-carcinogenic risks to the exposed population.

\section{Author Contribution}

Ajibare A.O.: Conceptualization, Formal Analysis, Methodology, Visualization and Writing -original draft, Review and editing; Ogungbile P.O.: Conceptualization, Project Administration, Resources, Investigation, Methodology, Visualization and Writing -original draft;
Ayeku P.O.: Conceptualization, Data Curation, Formal Analysis, Methodology, Writing -review and editing; and Akande J.A.: Supervision, Writing - review and editing.

\section{References}

Abubakar, A. Uzairu, A., Ekwumemgbo, P.A., Okunola, O.J. (2014): Evaluation of Heavy Metals Concentration in Imported Frozen Fish Trachurus Murphyi Species Sold in Zaria Market, Nigeria. American Journal of Chemistry 4(5): 137-154 DOI: 10.5923/j.chemistry.20140405.02

Adesuyi, A.A.; Ngwoke, M.O.; Akinola, M.O.; Njoku, K.L. and Jolaoso, A.O. (2016). Physicochemical Assessment of Sediments from Nwaja Creek, Niger Delta, Nigeria. Journal of Geoscience and Environment Protection, 4:1627.

Adeyeye El. And Ayoola PB (2010) Proximate composition, mineral and heavy metal contents of some freshwater fishes from Ikosi Dam, Ogbomoso, Nigeria. Electron $J$ Environ Agric Food Chem 10: 2883-2890.

Akinola, J.O., Olawusi-Peters, O.O. and Akpambang, V.O.E. (2020); Human Health Risk Assessment of TPHs in Brackish Water Prawn (Nematopalaemon hastatus, AURIVILLUS 1898). Heliyon. 6(1): 1-6. https://doi.org/10.1016/j.heliyon.2020.e03234

Akinola, J.O., Olawusi-Peters, O.O. and Akpambang, V.O.E. (2019): Ecological hazards of Total Petroleum Hydrocarbon in Brackish water white shrimp Nematopalaemon hastatus (AURIVILLUS 1898). Egyptian Journal of Aquatic Research). 45(3): 205-210. https://doi.org/10.1016/j.ejar.2019.07.004

Al-Mahaqer SA. and Ahmad AK (2015) Human Health Risk Assessment of Heavy Metals in Fish Species Collected from Catchments of Former Tin Mining. int J Res Stud Sci Eng.Technol 2: 9-21.

Baki, M.A., Hossain, M.M., Akter, J., Quraishi, S.B., Haque Shojib, M.F., Atique Ullah, A.K.M., Khan, M.F., (2018). Concentration of heavy metals in seafood (fishes, shrimp, lobster and crabs) and human health assessment in Saint Martin Island, Bangladesh. Ecotoxicol. Environ. Saf. 159, 153-163.

Carroll R.W.H. and Warwick, J.J. (2017) The importance of dynamic mercury water column concentrations onbody burdens in a planktivorous fish: A bioenergetic and mercury mass balance perspective. Ecol Modell 364: 6676.

Chahid A (2016) Quantification of metallic trace elements (cadmium, lead, and total mercury) of certain fishery products landed in the Essaouira-Dakhla zone: Health risk assessment, PhD thesis, IBN ZOHR University, Faculty of Sciences (Morocco), $172 \mathrm{p}$.

Dimari, G. A., Abdulkarim, F. I., Akan, J. C. and Garba ST. (2008): Metal concentrations in Tissues of Tilapia galier, Clarias lazera, and Osteoglosidae caught from Alau Dam, Maiduguri, Borno State, Nigeria. Am J Environ Sci. 4(4):373-379. https://doi.org/10.3844/ajessp.2008.373.379

Edward, J. B., Idowu, E. O., Oso, J. A., Ibidapo, O. R. (2013). Determination of Heavy Metal Concentration in Fish Samples, Sediment and Water from Odo-Ayo River in Ado-Ekiti, Ekiti-State, Nigeria. International Journal of Environmental Monitoring and Analysis.1(1): 27-33.

Falcoä G, Lobet J M L, Bocio A, Domingo J L (2006) Daily Intake of Arsenic, Cadmium, Mercury, and Lead by 
Consumption of Edible Marine Species. J Agric Food Chem 54: 6106-6112.

Food and Agricultural Organization (FAO).(2007). Heavy metals regulations: part 1. Legal Notice No. 66. www.faolex.fao.org/docs/pdf/eri42405.pdf

Isibor, P. O. and Imoobe, T. O. T. (2017). Comparative Analysis of Contaminability between C. gariepinus and T. mariae. Annual Research and Review in Biology. 16(5): 1-14

Javed M, Usmani N, Ahmad I, Ahmad M (2015) Studies on the oxidative stress and gill histopathology in Channa punctatus of the canal receiving heavy metal-loaded effluent of Kasimpur Thermal Power Plant. Environ Monit Assess 187:4179. doi:10.1007/s10661-014-4179-6

Javed M. and Usmani N. (2016): Accumulation of heavy metals and human health risk assessment via the consumption of freshwater fish Mastacembelus armatus inhabiting, thermal power plant effluent loaded canal. SpringerPlus 5:776 DOI 10.1186/s40064-016-2471-3

Jimoh LA, Amoo IA, Adebayo MA (2004) Evaluation of the burdens of heavy metals in five commercially important fishes from different locations in Kainji Lake, p: 702-709.

Li Z, Zhang D, Wei Y, Luo L, Dai T. (2014): Risk assessment of trace elements is cultured from freshwater fishes from Jiangxi Provence, China. Environ Monit Asses.186:21852194.

Liu, Q., Liao, Y., Shou, L., 2018. Concentraion and potential health risk of heavy metals in seafoods collected from Sanmen Bay and its adjacent areas, China. Mar. Pollut. Bull.131, 356-364.

Liu, Q., Xua, X, Zenga, J., Shia, X, Liaoa, Y., Dua, P., Tanga, Y, Huanga, W, Chena, Q, Shou, L. (2019): Heavy metal concentrations in commercial marine organisms from Xiangshan Bay, China, and the potential health risks. Marine Pollution Bulletin 141: 215-226.

Manavia, P.N., and Mazumder A (2018) Potential risk of mercury to human health in three species of fish from the southern Caspian Sea. Mar Pollut Bull, 130: 1-5.

Milam C, Maina HM, Onyia LU, and Ozoemena PE (2012) Heavy metal pollution in benthic fishes from Kiri Dam in Guyuk local government area of Adamawa State, Nigeria. African Journal of Biotechnology 11: 11755-11759.

NYSDOH (New York State Department of Health) (2007) Hopewell precision area contamination: appendix C-NYS $\mathrm{DOH}$. Procedure for evaluating potential health risks for contaminants of concern. http://www.health.ny.gov/en vironmental/investigations/hopewell/appendc.htm

Núñez R, García, M A, Alonso J, and Melgar M J (2018) Arsenic, cadmium and lead in fresh and processed tuna marketed in Galicia (NW Spain): Risk assessment of dietary exposure. Sci Total Environ, 627:322-331.

Olaosebikan, B. D. and Raji, A. (2013): Field guide to Nigerian Freshwater Fishes. Revised Edition. Federal College of Freshwater Fisheries Technology, New Bussa, Nigeria, $144 \mathrm{pp}$.

Olawusi-Peters, O.O. (2021). Evaluation of Water Quality and Heavy Metal Pollution in the Shoots and Roots of Aquatic Plants. Turkish Journal of Fisheries and Aquatic Sciences, 21, 443-450. http://doi.org/10.4194/1303-2712v21_9_03

Olawusi-Peters, O.O. and Adejugbagbe, K.I. (2020): Health Risk Assessment of Heavy Metals in Clarias gariepinus (Burchell, 1822) from Fish Mongers within Akure Metropolis, Ondo State, Nigeria. International Journal of Animal and Veterinary Sciences. 14 (5): 55-59.
Olawusi-Peters, O.O.; Ajibare, A.O. and Akinboro T.O. (2019): Ecological and Health Risk from Heavy Metal Exposure to Fish. Journal of Fisheries Research. 3(2):10-14.

Olawusi-Peters, O. O., Akinola, J. O. and Jelili, O. A. (2017). Assessment of Heavy Metal Pollution in Water, Shrimps and Sediments of some Selected Water Bodies in Ondo State. Journal of Research in Agricultural Science. 5(2): 55-66.

Omobepade, B.P. Akinsorotan, A.M.; Ajibare, A.O.; Ogunbusola, E.M.; Ariyomo, T.O. Jimoh, J.O. Odeyemi, K.M. Okeke, O.S.; Falabake, M.A.; Adeniji, S.M. and Adedapo, A.M. (2020): Heavy Metal Concentrations in the White Shrimp Nematopalaemon hastatus and their Associated Ecological and Health Risk in the Nigerian Continental Shelf. Egyptian Journal of Aquatic Biology and Fisheries 24 (2): $301-316$.

Onuoha, S. C. Anelo, P. C. and Nkpaa, K. W. (2016): Human Health Risk Assessment of Heavy Metals in Snail (Archachatina marginata) from Four Contaminated Regions in Rivers State, Nigeria. American Chemical Science Journal. 11(2): 1-8.

Orosun MM, Tchokossa P, Orosun RO, Akinyose FC, Ige SO, and Oduh VO. (2016) Determination of Selected Heavy Metals and Human Health Risk Assessment in Fishes from Kiri Dam and River Gongola, Northeastern Nigeria. J Phys Chem Biophys 6(4): 229. doi:10.4172/21610398.1000229

Rajeshkumar S, Li, X (2018) Bioaccumulation of heavy metals in fish species from the Meiliang Bay, Taihu Lake, China. Toxicol Rep 5:288-295.

Raknuzzaman, M., Ahmed, M.K., Islam, M.S., Habibullah-AlMamun, M., Tokumura, M., Sekine, M., Masunaga, S., (2016). Trace metal contamination in commercial fish and crustaceans collected from coastal area of Bangladesh and health risk assessment. Environ. Sci. Pollut. Res. 23, 17298-17310.

Ramos A L(2012) Risk assessment of methylmercury from fish consumption in OAHU, HAWAll using hair as a biomarker of exposure, PhD thesis, Faculty of San Diego State University, $83 \mathrm{p}$.

Sajjad Khan, Robina Farooq, Shagufta Shahbaz, Mohammad Aziz Khan and Maria Sadique (2009). Health risk assessment of heavy metals for population via consumption of vegetables. World Applied Sciences Journal, 6, (12): 1602 - 1606.

United States Environmental Protection Agency (USEPA) (2017) Human Health Risk Assessment https://www.epa.gov/risk/human-health-riskassessment

United States Environmental Protection Agency (USEPA) (2011). Exposure factors handbook: 2011 Edition. EPA/600/R-090/052F. Office of research and development, Washington, D.C.

USEPA (2012). Waste and cleanup risk assessment. http://www2.epa.gov/risk/waste-and-cleanup-riskassessment

Vieira C, Morais S, Ramos S, Delerue-MatosC, Oliveira M B P P (2011) Mercury, cadmium, lead and arsenic levels in three pelagic fish species from the Atlantic Ocean: Intraand inter-specific variability and human health risks for consumption. Food Chem Toxicol 49: 923-932.

WHO (2005). Background document for development of WHO guidelines for nickel in drinking-water quality and fish. WHO/Sde/Wsh/05.08/55 English Only. 